\title{
The Organic Planting Ribbon (OPR) Made of Banana Sheath and Its Effect on Rice Growth in Direct Seedling System
}

\author{
G. Djoyowasito ${ }^{1}$, W. H. Utomo ${ }^{2}$, B. Suharto ${ }^{1} \&$ Nur Basuki $^{3}$ \\ ${ }^{1}$ Faculy of Agricultural Technology, University of Brawijaya, Malang, Indonesia \\ ${ }^{2}$ International Research Centre for Mining and Degraded Land; University of Brawijaya, Malang, Indonesia \\ ${ }^{3}$ Research Centre for Tubers and Root Crops University of Brawijaya, Malang, Indonesia \\ Correspondence: G. Djoyowasito, Faculy of Agricultural Technology, University of Brawijaya, Malang, \\ Indonesia. E-mail: wanihadi@ub.ac.id
}

Received: February 17, 2014 Accepted: March 25, 2014 Online Published: May 15, 2014

doi:10.5539/jas.v6n6p10 URL: http://dx.doi.org/10.5539/jas.v6n6p10

\begin{abstract}
The research was conducted to examine the characteristics of organic planting ribbon (OPR) made of banana sheath and its effect on rice growth planted with a direct seedling system. The experimental treatments consisted of two factors, i.e.: the material for ribbon decomposer (Urea and Ammonium Sulfate, AS), and the composition of ribbon material (100: 0, 90: 10 and 80: 20 of water hyacinth and banana sheath mixture). The experiment was arranged Randomized Block Design Factorial with the ribbon decomposer as the main factor and done in three replications. The results demonstrated that the addition of banana sheath increased the tensile strength and penetration resistance of OPR. The increase of OPR tensile strength had advantages because the materials did not easily break up. On the other hand, although there was an increase of the penetration resistance, the value was still below the maximum root growth pressure, so that it did not inhibit seed germination. The ribbon characteristics were influenced either by ribbon decomposer or ribbon material proportion. Increasing levels of banana sheath the $\mathrm{C} / \mathrm{N}$ ratio and lowered the speed of decomposition. The use of OPR in rice direct seedling did not influence germination percentage and germination rate.
\end{abstract}

Keywords: conservation farming, minimum tillage, zero tillage, tensile strength, penetration resistance

\section{Introduction}

Theoretically, in rice farming the direct seedling will be more beneficial compared to the conventional transplanting rice system because it reduces cost and shortens cropping duration (Mann et al., 2007; Minoru, 2006). However, up to now the direct seedling in rice farming still lacks of interest. According to Mann et al. (2007) the reasons for these phenomena are: (a) the seed is located on land surface which causes a random of row crops due to the blow of wind, rain or irrigation water, (b) the plant is unable to germinate properly, (c) weeds grow faster than the rice crop. In addition, in direct seedling system the seed is vulnerable to pests, rodents and birds (Minoru, 2006), and this make direct seedling yields un-uniform crop stands (Sekiya et al., 2004). Looking these problems, Mustafa et al. (2002) has developed organic planting ribbon (OPR) for planting rice crops in direct seedling system.

OPR is a single layer sheet made of natural materials which contain lignin and cellulose, and at certain distance a place is created which is filled with 1-2 rice seeds. The thickness of sheet varies between 1-2 $\mathrm{mm}, 4-5 \mathrm{~cm}$ in width, and the length is in accordance with the requirement. In order to facilitate the application, OPR can be rolled. Djoyowasito et al. (2009) make OPR from a mixture of water hyacinth (Eichornia crassiceps (Mart) Solm) stem and unused news paper with thickness of 1-2 mm, width of 4-5 cm. The ideal OPR should have high tensile strength, but low penetration resistance. A high tensile strength is required to facilitate the application of OPR. If the tensile strength is higher, it will not be failed easily. Thus, the application of OPR will be easier. OPR should not retard rice seed germination; hence, it should have a low penetration resistance. The penetration resistance of OPR should not exceed the maximum germination strength of rice seeds. As a preliminary reference, the use of maximum penetration resistance is $1.5 \mathrm{MPa}$; the maximum penetration resistance in which root cans growth (Eavis et al., 1969) is used. To decompose lignin in the ribbon they use Urea. The utilization of urea would have an additional benefit because it can be used by rice seedling. It was observed that OPR has low tensile strength about 
$35 \mathrm{Nm}^{-2}$; thus, OPR was broken easily when applied. The use of urea as the lignin decomposer has unsatisfactory result since it makes the decomposition of OPR fast. Then, OPR does not able to withstand for a longer time. In addition, it should be careful with the utilization of unused newspaper as it contains lead $(\mathrm{Pb})$ which is toxic to human life.

The success keys of OPR application is that the materials should not break up easily, not inhibit seed germination and be long-lasting. Therefore, it is necessary to modify the design of OPR by replacing the ribbon with more resistant materials. In our study, we observed that banana (Mussa paradisiaca) sheath had higher tensile strength of $15.7 \mathrm{~N} \mathrm{~cm}^{-2}$ when compared to that of water hyacinth which only had tensile strength of $13,00 \mathrm{~N} \mathrm{~cm}^{-2}$ (Djoyowasito et al., 2007). It is considered that the use of banana sheath as a raw material of OPR will yield a better quality of OPR. In addition, Pometto and Crawford (1986) demonstrate that the decomposition of lignin and cellulose is influenced by the acidity of environmental conditions. Therefore, it is worthwhile to explore another lignin decomposer in OPR. As urea is utilized, this lignin decomposer should also contain nitrogen necessary for rice growth. By looking these criteria, it seems Ammonium Sulfate is the proper choice.

The objective of the experiment described here was to investigate whether the use of banana sheath yielded a better quality of OPR than that of water hyacinth. To obtain this objective, we observed the characteristics of banana sheath's OPR, those of water hyacinth's OPR, and their effects on rice growth in direct seedling system.

\section{Materials and Methods}

\subsection{OPR Preparation and Experimental Treatments}

Organic planting ribbon (OPR) was made according to the method described by Djojowasito et al. (2009), and a rice seed was put in the OPR at a distance of $20 \mathrm{~cm}$. In this study, two raw materials were used to make OPR. These materials were water hyacinth (Eichornia crassipes (Mart) Solm) stem and banana (Mussa paradisiaca) sheath. Some characteristics of water hyacinth and banana sheath were presented in Table 1. Urea $\left(\mathrm{CO}\left[\mathrm{NH}_{2}\right]_{2}\right)$ and Ammonium sulfate (AS, $\left[\mathrm{NH}_{4}\right]_{2} \mathrm{SO}_{4}$ ) were used as the decomposer of OPR.

Table 1. Some characteristics of banana sheath and water hyacinth used for OPR

\begin{tabular}{lcc}
\hline Characteristics & Water hyacinth & Banana sheath \\
\hline Alpha cellulose (\%) & 43.56 & 61.05 \\
Lignin (\%) & 25.76 & 9.20 \\
C (\%) & 5.24 & 4.40 \\
Pentosa (\%) & 16.25 & 14.00 \\
Silica (\%) & 8.55 & $<1.00$ \\
Ash (\%) & 8.00 & 2.07 \\
Tensile strength $(\mathrm{kPa})$ & 130 & 157 \\
\hline
\end{tabular}

The treatments studied in the study included three levels of water hyacinth stem and banana sheath, i.e. $100 \%$ water hyacinth (WH); 90\% water hyacinth and 10\% banana sheath (WH90BS10); 80\% water hyacinth and 20\% banana sheath (WH80BS20), and 2 kinds of lignin decomposers, i.e. Urea (U) and Ammonium Sulfate (AS). The concentration of urea and ammonium sulfate were $1 \%$ of the OPR weight. Furthermore, there was conventional direct seedling (without OPR) as the control.

These 6 treatment combinations and additional control treatments were arranged in a Randomized Block Design (RBD) with three replications.

\subsection{Experimental Procedure}

Soil tillage was performed by plowing and harrowing, and then direct seedling was accomplished. Rice was planted on plot of $6.0 \times 5.0 \mathrm{~m}$, and the distance between OPR was $20 \mathrm{~cm}$.

The data collection involved the properties of OPR (organic carbon, total nitrogen, tensile strength, and penetration resistance), percentage of germination, rate of germination, seed viability and plant height.

Organic C was determined by Walkley and Black wet oxidation method (Soil Survey Laboratory Staff, 1992) and $\mathrm{N}$ content was measured by Kjeldhal method (Bremner \& Mulyaeny, 1982). Tensile strength was measured by Brazilian Test in air condition (Locke, 2010). The tensile strength $\left(\mathrm{N} \mathrm{m}^{-2}\right)$ was the value of tensile stress at the 
initial tensile failure. Penetration resistance was measured by "cone penetrometer", in which penetration resistance $\left(\left(\mathrm{N} \mathrm{m}^{-2}\right)\right.$ was a measure of stress when the cone penetrated the OPR. Organic $\mathrm{C}$ and total $\mathrm{N}$ were measured weekly for 3 weeks after planting. Alpha cellulose and Lignin were determined by Chesson method (Datta, 1981), pentose with gravimetric method by using phloroglusinol (Wise, 1944), silica was extracted with Ammonium heptamolibdate and the concentration was read by UV-Vis spectrophometer and ash content with gravimetric method (Sluiter et al., 2008).

The rate of seed germination and seed viability were observed for 7 days. The rate of seed germination (RG) was then calculated by the Equation (1).

$$
\mathrm{RG}=\frac{\sum \mathrm{Gn}}{\sum(\mathrm{Gn} \times \mathrm{Dn})} \times 100 \%
$$

where: $\mathrm{Gn}$, is the number of seeds that germinate on the day i (-) and Dn is the number of days (days).

Seed viability (SV) was calculated with the Equation (2),

$$
\mathrm{SV}=\frac{\text { No.of seed germinate }}{\text { No.of total seed }} \times 100 \%
$$

Plant height was measured on day 7, 15,30 and 45 after seeding. The lower limit of plant height measurement was right on the surface of the ground and the upper limit was the highest on the tip of leaf.

ANOVA with the probability level of $5 \%$ was employed to analyze the data. When there was a significant different, the LSD test was performed.

\section{Results and Discussions}

\subsection{Organic Planting Ribbon (OPR) Characteristics}

The tensile strength of OPR was not significantly influenced by the interaction between raw materials of OPR and lignin decomposer. However, it was significantly influenced, either by the proportion of raw materials (Table 2) or ribbon decomposer (Table 3). The result in Table 2 showed an addition of banana sheath in OPR materials increased tensile strength and penetration resistance of OPR, and both tensile strength and penetration resistance of OPR increased with the percentage rise of banana sheath proportion. The highest tensile strength $\left(426.75 \mathrm{~N} \mathrm{~m}^{-2}\right)$ and penetration resistance were observed for the OPR made of $80 \%$ water hyacinth and $20 \%$ banana sheath. Banana sheath contained higher alpha cellulose compared to water hyacinth (Table 1). Therefore, the percentage rise of banana sheath in OPR would increase alpha cellulose content of OPR. According to Locke (2010) cellulose has a tensile strength which is a half of structural steel, and this characteristic will play an important role in determining the tensile strength of OPR.

Table 2. Effects of raw material proportion on the OPR tensile strength and penetration resistance

\begin{tabular}{lcc}
\hline Organic planting ribbon (OPR) materials & Tensile strength (kPa) & Penetration resistance (kPa) \\
\hline $100 \%$ water hyacinth & $107.80 \mathrm{a}$ & $53.04 \mathrm{a}$ \\
$90 \%$ water hyacinth: $10 \%$ banana sheath & $294.00 \mathrm{~b}$ & $72.49 \mathrm{~b}$ \\
$80 \%$ water hyacinth: $20 \%$ banana sheath & $426.75 \mathrm{c}$ & $86.63 \mathrm{c}$
\end{tabular}

*) means followed by the same letters are not significantly different $(\mathrm{p}=0.05)$

The statistical analysis showed that kinds of ribbon decomposer only influenced the tensile strength of OPR, instead of the OPR penetration resistance. The result in Table 3 showed that the use of Ammonium sulfate as a ribbon decomposer produced higher tensile strength OPR than that of Urea. The mechanism by which OPR with Ammonium Sulfate as the ribbon decomposer had a higher tensile strength has not been understood yet. Pometto and Crawford (1986) show that although the mineralization of cellulose and lignin is optimal at the lightly neutral $\mathrm{pH}$, the solubility of lignin and cellulose increase in line with the increasing $\mathrm{pH}$, and are optimal in alkaline condition. Ammonium sulfate is a strong acid nitrogen fertilizer which will cause more acid condition.

In this condition, lignin and cellulose were less soluble. Hence, it was reasonable that OPR had higher tensile strength. 
Table 3. Effect of ribbon decomposer on OPR tensile strength

\begin{tabular}{lc}
\hline Organic Planting Ribbon (OPR) decomposer & Tensile strength (kPa) \\
\hline Urea & $199.30 \mathrm{a}$ \\
Ammonium sulfate & $353.15 \mathrm{~b}$
\end{tabular}

*) means followed by the same letters are not significantly different $(\mathrm{p}=0.05)$.

It was observed that the ribbon had been completely decomposed on day 25 after application. Therefore, the measurement of carbon and nitrogen content was only done until 3 weeks after application. The results of statistical analysis showed that the OPR carbon content was not significantly influenced by the interaction between ribbon decomposer and material proportion. The OPR carbon content was only significantly influenced by the proportion of water hyacinth and banana sheath. As a result of decomposition, both organic- $\mathrm{C}$ and nitrogen contents in the OPR decreased over the time.

If the change in $\mathrm{C} / \mathrm{N}$ ratio of OPR can be recommended as the rate of composition, then it can be concluded that the model of OPR decomposition follows the decay model, i.e.

$$
\mathrm{C} / \mathrm{N} \text { ratio }=\mathrm{a}+\mathrm{b} \mathrm{e}^{\mathrm{t}}
$$

In which: $\mathrm{t}$ is time (days after application), and $\mathrm{a}$ and $\mathrm{b}$ are constant values obtained from the experiment

The resulted model (Figure 1) showed that an increase of banana sheath in OPR lowered the rate of decomposition. It seemed that the rate of decomposition was more influenced by the alpha cellulose content of the materials rather than carbon or pentose content. As shown in Table 1, water hyacinth had a higher $\mathrm{C}$ and pentose content compared to banana sheath. However, the alpha cellulose content in banana sheath was higher than that in the water hyacinth.

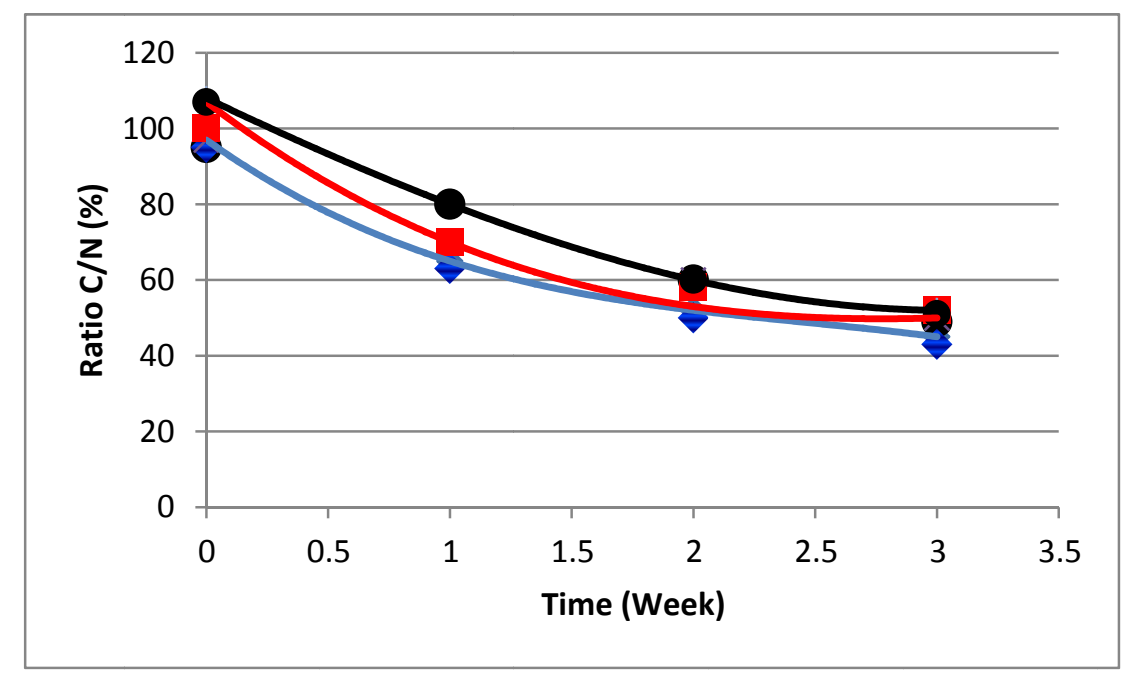

Figure 1. $\mathrm{C} / \mathrm{N}$ ratio of OPR in a different proportion of water hyacinth and banana sheath. ( $\bullet$ ) $100 \%$ water hyacinth $\left(\mathrm{C}_{1}\right) ;(\square) 90 \%$ water hyacinth:10\% banana sheath $\left.\left(\mathrm{C}_{2}\right) ;(-)\right) 80 \%$ water hyacinth: $20 \%$ banana sheath $\left(\mathrm{C}_{3}\right)$

\subsection{Plant Performance}

It was observed that the percentage of germination was not significantly influenced by OPR decomposer and OPR proportion materials, with the value of $97-98.5 \%$ (compared to non-Ribbon). It seems that the highest penetration resistance of OPR used in this study $(86.63 \mathrm{kPa})$ did not become the limiting factors for seed germination. Misra et al. (1986) observe the maximum root growth pressure of pea, cotton and sun flower is $238 \mathrm{kPa}$. Azam et al. (2013) find out that the root growth pressure of 2 days old Pisum sativum seedling varies from 150-150 kPa. A large variation of root growth pressure of peas has been shown by Clark et al. (1999), i.e. ranging from 0.3 to $1.3 \mathrm{MPa}$ which depends on the cultivars. 
The experimental result presented in Table 4 showed that the addition of banana sheath into OPR did not significantly influence the rate of germination.

Table 4. Effect of OPR raw material proportion on germination rate

\begin{tabular}{lc}
\hline Organic planting ribbon (OPR) materials & Germination Rate $\left(\% \mathrm{~d}^{-1}\right)$ \\
\hline $100 \%$ water hyacinth & 28.6 \\
$90 \%$ water hyacinth: $10 \%$ banana sheath & 25.2 \\
$80 \%$ water hyacinth: $20 \%$ banana sheath & 26.9 \\
Control (without OPR) & 26.1 \\
\hline
\end{tabular}

*) means followed by the same letters are not significantly different $(\mathrm{p}=0.05)$.

The result presented in Table 5 showed that until 15 days old, the height of rice seedling was not significantly different for all treatments. However, starting from 30-day observation, seedling height on the OPR treated with ammonium sulfate was higher than that with urea or the control. A better growth of rice seedling on the OPR treated with ammonium sulfate was probably partly due to the difference compound released by the two fertilizers. Ammonium sulfate would release $\mathrm{NH}_{4}{ }^{+}$which could be absorbed by the negative charge of clay, and then absorbed by the plant. In addition, ammonium sulfate also provided sulfur (S) to the plant. Fageria et al. (2010) has shown that up to $120 \mathrm{~kg} \mathrm{~N} / \mathrm{ha}$ application rate, the grain yield of lowland rice treated with ammonium sulfate is higher than that with urea treatment.

Table 5. Effect of ribbon decomposer on OPR in terms of the height of rice seedling

\begin{tabular}{lllll}
\hline \multirow{2}{*}{ Ribbon decomposer } & \multicolumn{4}{c}{ Plant height (cm) on: } \\
\cline { 2 - 5 } & day 7 & day 15 & day 30 & day 50 \\
\hline Ammonium sulfate & 15,1 & 20,6 & $34.6 \mathrm{~b}$ & $54.3 \mathrm{~b}$ \\
Urea & 13,0 & 17.8 & $27.2 \mathrm{a}$ & $42,8 \mathrm{a}$ \\
Control (without OPR) & $12,7 \mathrm{NS}$ & $18,4 \mathrm{NS}$ & $28.6 \mathrm{a}$ & $41.7 \mathrm{a}$ \\
\hline
\end{tabular}

The experimental results discussed above demonstrated that the addition of banana sheath increased the tensile strength and penetration resistance of OPR. The increase of OPR tensile strength would have advantages because the materials did not easily break up. When there was an increase of penetration resistance, however, the value was still below the maximum root growth pressure. Thus, it did not inhibit seed germination. The addition of banana sheath increased the $\mathrm{C} / \mathrm{N}$ ratio of OPR. This would make the OPR lasting for a longer time. The use of ammonium sulfate as the decomposer improved the growth performance of rice seedling.

\section{Acknowledgment}

This work was partly sponsored by University of Brawijaya for the first author's doctoral study at University of Brawijaya. We would also like to thank PPIKID staffs at University of Brawijaya for their assistance in the manuscript preparation.

\section{References}

Adhikari, U., Justice, S., Tripathi, J., \& Bhatta, M. R. (2007). Performance evaluation of non-puddled rice transplanting methods. Paper presented at $25^{\text {th }}$ National Summer Crop Workshop, Nepal.

Azam, G., Grant, C. D., Misra, R. K., Murray, R. S., \& Nuberg, I. K. (2013). Growth of tree roots in hostile soil: a comparison of root growth pressures of tree seedlings with peas. Plant and Soil, 368, 569-580.

Bremner, J. M., \& Mulvaney, C. S. (1982). Nitrogen-total. In A. L. Page, R. H. Miller, \& D. R. Keeney (Eds.), Methods of Soil Analyses, Part 2. Chemical and Mineralogical properties (pp. 595-624). Madison: American Society of Agronomy and Soil Science Society of America Inc. 
Clark, L. J., Bengough, A. G., Whalley, W. R., Dexter, A. R., \& Barraclough, P. B. (1999). Maximum axial root growth pressure in pea seedlings: effects of measurement techniques and cultivars. Plant and soil, 209(1), 101-109.

Datta, R. (1981). Acidogenic fermentation of lignocellulose-acid yield and conversion of components. Biotechnology and Bioengineering, 23, 2167-2170.

Djoyowasito, G., Ekoyanto, P., \& Maides, G. (2009). The study of the performance of organic planting ribbon (OPR) on the growth and yield of lowland rice (Oryza sativa L) (in Indonesian). Jurnal Teknologi Pertanian University of Brawijaya, 10, 200-204.

Djoyowasito, G., Mustofa, A., \& Kusuma, S. K. (2007). Manufacture and testing of sheet organic mulch from water hyacinth and banana sheath (in Indonesian). Jurnal Teknologi Pertanian University of Brawijaya, 8, 110-118.

Eavis, B. W., Ratliff, L. F., \& Taylor, H. M. (1969). Use of a dead-load technique to determine axial root growth pressure. Agron. J., 61, 640-643.

Fageria, N. K., Dos Santos, A. B., \& Moares, M. F. (2010). Influence of urea and ammonium sulfate on soil acidity indices in lowland rice production. Communications in Soil Science and Plant Analysis, 41, 1565-1575.

Locke, J. (2010). Tensile strength of cellulose fiber. Retrieved from http://en.allexperts.com/q/Biology-664/2010/9/Tensile-strength-cellulose-fibers.htm

Mann, R. A., Ahmad, S., Hassan, G., \& Baloch, M. S. (2007). Weed management in direct seeded rice crop. Pakistan Jour. Weed Sci. Res., 13, 219-226.

Minoru, Y. (2006). Direct seeding of paddy-rice on paddy field; The iron coating seed which solved a float seedling and the issue of bird damage. Hojo to Dojo, 38, 21-27.

Misra, R. K., Dexter, A. R., \& Alston, A. M. (1986). Maximum axial and radial growth pressures of plant roots. Plant and Soils, 95, 315-326.

Mustofa, A., Djojowasito, G., \& Rumekso, W. (2002). The testing of organic planting ribbon on lowland rice (Oriza sativa L.) (in Indonesian). Jurnal Teknologi Pertanian, University of Brawijaya, 3, 10-13.

Pometto, A. L., \& Crawford, D. L. (1986). Effects of $\mathrm{pH}$ on Lignin and Cellulose Degradation by Streptomyces viridosporus. Appl Environ Microbiol., 52, 246-250.

Sekiya, H., Ogiwara, H., Kimura, S., Otani, R., Yaji, Y., Morita, S., .. Watanabe, H. (2004). The rice direct-seeding system using multiple seed pellets in northern Tohoku. Rice is Life. International Year of Rice 2004.

Sluiter, A., Hames, B., Ruiz, R., Scarlata, C., Sluiter, J., \& Templeton, D. (2008). Determination of ash in biomass. National Renewable Energy Laboratory.

Soil Survey Laboratory Staff. (1992). Soil survey laboratory methods manual. Soil Survey Investigation Report No. 42, Version 2.0, USDA.

Wise, L. E. (1944). Wood Chemistry. New York: Reinhold Publisher Corporation.

\section{Copyrights}

Copyright for this article is retained by the author(s), with first publication rights granted to the journal.

This is an open-access article distributed under the terms and conditions of the Creative Commons Attribution license (http://creativecommons.org/licenses/by/3.0/). 